\title{
Geochemistry and tectonic setting of the volcanic host rocks of VMS mineralisation in the Qezil Dash area, NW Iran: implications for prospecting of Cyprus-type VMS deposits in the Khoy ophiolite
}

\author{
Ali IMAMALIPOUR ${ }^{1, *}$ and Samaneh BARAK ${ }^{1}$ \\ 1 Urmia University, Department of Mining Engineering, 57153-165 Urmia, Islamic Republic of Iran
}

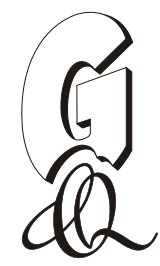

Imamalipour, A., Barak, S., 2019. Geochemistry and tectonic setting of the volcanic host rocks of VMS mineralisation in the
Qezil Dash area, NW Iran: implications for prospecting of Cyprus-type VMS deposits in the Khoy ophiolite. Geological Quarterly, 63 (3): 435-448, doi: 10.7306/gq.1479

Associate editor: Tomasz Bajda

The uppermost part of the Khoy ophiolite includes submarine volcanic lavas. These rocks are found as two different types including basaltic pillow lavas and andesitic to andesitic basalt massive-sheet lavas known as the Qezil Dash unit. These last rocks host volcanogenic massive sulphide mineralisation (VMS). Concordant small lenticular massive sulphides associated with widespread stockworks, extensive wall rock alteration and simple mineralogical parageneses are characteristic of this mineralisation. The Qezil Dash lavas are characterized by HFSE depletion (such as in Nb, Zr, and Hf) and LILE enrichment, low $\mathrm{Yb}, \mathrm{Y}$ and $\mathrm{Ni}$ contents and low $\mathrm{Zr} / \mathrm{Hf}$ and $\mathrm{Nb} / \mathrm{Ta}$ ratios. These rocks have low Ti contents and are of $\mathrm{LKT}$ type. These geochemical characteristics can be interpreted as indicating SSZ magmatism and suggesting that the Qezil Dash rocks belong to an early stage of island arc formation. Geochemically, this host rock is comparable with the Lasail unit, part of a volcanic sequence within the Oman ophiolite. In the Troodos and Oman ophiolites VMS mineralisation has occurred at the contacts of MOR-basalt and island arc tholeiite (IAT) lavas, so prospecting for VMS deposits in the Khoy area should be established based on geochemical investigations of the volcanic rocks and recognition of their field boundaries.

Key words: geochemistry, massive sulphide mineralisation, IAT, ophiolite, Khoy, Iran.

\section{INTRODUCTION}

Volcanogenic massive sulphide (VMS) deposits are formed in marine tectonic settings (Galley et al., 2007). The simultaneous occurrence of three significant factors including magmatism, seismicity, and high-temperature hydrothermal venting controls the VMS mineralisation (Shanks and Thurston, 2012). Occurrences of VMS deposits have an affiliation with a variety of tectonic environments such as mid-ocean ridge (MOR), island arc (or so-called SSZ, Supra Subduction Zone), back-arc basin and continental rift/back-arc basin settings (Schandl and Gorton, 2002; Shanks and Thurston, 2012). These deposits typically occur in the form polymetallic massive sulphide lenses, which are known as the major sources of $\mathrm{Zn}$, $\mathrm{Cu}, \mathrm{Pb}, \mathrm{Ag}$, and $\mathrm{Au}$, and significant sources of Co, Sn, Se, Mn, $\mathrm{Cd}, \mathrm{In}, \mathrm{Bi}, \mathrm{Te}, \mathrm{Ga}$, and Ge (Galley et al., 2007). Tonnage reservoirs of VMS deposits and their metal contents are log-normally

\footnotetext{
* Corresponding author, e-mail: a.imamalipour@urmia.ac.ir
}

Received: August 23, 2018; accepted: December 19, 2018; first published online: July 8,2019 distributed, though, as shown by geometric means that range from 2.7 to 7.1 Mt (Sangster, 1977; Franklin et al., 2005).

There are three main groups of VMS deposits associated with marine felsic to intermediate volcanic rocks, comprising: (1) Cyprus-type (Cu category), associated with marine mafic volcanic rocks, (2) Besshi-type (Cu-Zn category), associated with clastic terrigenous deposits and marine mafic volcanic rocks, and (3) Kuroko-type (Cu-Pb-Zn category; Cox and Singer, 1986; Herrington et al., 2005; Galley et al., 2007). Massive to disseminated iron, copper and occasionally zinc sulphide deposits hosted by mafic volcanic rocks, located on the tops of ophiolite sequences, have been described extensively in the literature as "Cyprus type" (Sawkins, 1976; Frankline et al., 1981; Laznicka, 1985).

As described by Evans (2009), the ores with a volcanic affiliation show a progression of types. The Cyprus types are found associated with tholeiitic mafic volcanic rocks, usually in the form of ophiolites and presumably formed at oceanic or back-arc spreading ridges. These are essentially cupriferous pyrite bodies. Well-known examples include the Tethyan ophiolites in Cyprus (Troodos), and Oman (Semail), Canada (Flin Flon mining district) and Turkey (Ergani; Galley et al., 2007, and references therein). Associated with the early part of the main calc-alkaline stage of island arc formation are the Besshi-type deposits. The more felsic volcanics, developed at a later stage in island arc evolution, have a more varied metal as- 


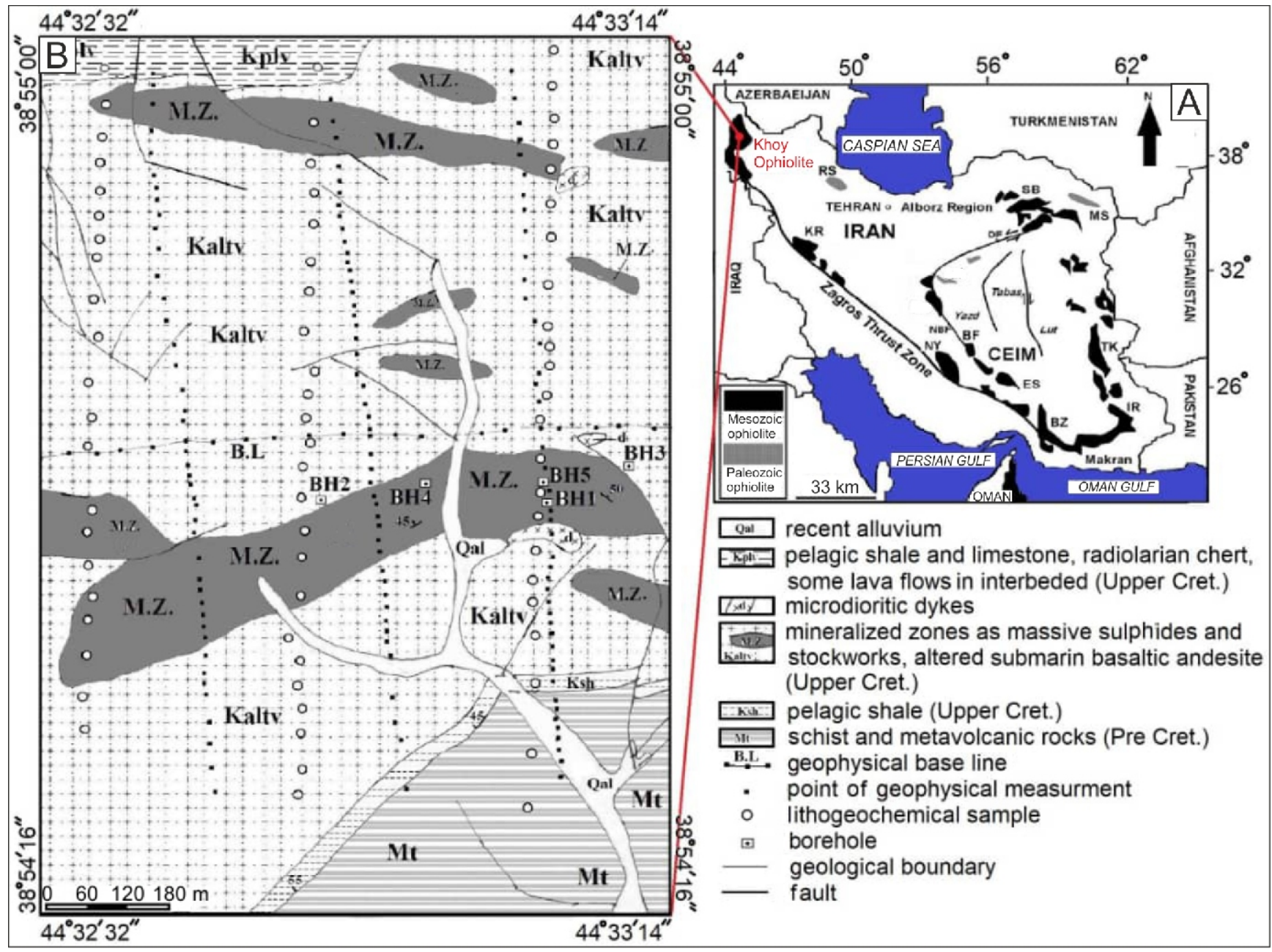

Fig. 1A - simplified schematic map of the distribution of Iranian ophiolites and of the Mesozoic (Nain and Ashin) and Paleozoic (Jandaq and Posht-e-Badam) ophiolites of the Central East Iranian Microcontinent (CEIM) investigated; B - geological map of the Khoy area at 1:5000 scale

The study area is marked by a red rectangle; ophiolites: BF - Baft, BZ - Band-e-Ziarat, ES - Esfandagheh, IR - Iranshahr, KR Kermanshah, MS - Mashhad, NY - Neyriz, RS - Rasht, SB - Sabzevar, SM - Semail, TK - Tchehel Kureh; faults: DF - Doruneh, NBF - Nain-Baft

sociation. They are called Kuroko-type deposits (Evans, 2009). As represented by Pearce and Peate (1995), geochemical studies of incompatible trace and rare earth elements (REEs) are capable of reflecting the tectonic environment in which VMS deposits exist.

Several examples of VMS mineralisation are found in the uppermost part of the submarine lavas of the Khoy ophiolite, and in some cases just below the shale, chert and pelagic limestone deposits. The Qezil Dash district is one of them, which is located $\sim 90 \mathrm{~km}$ west of the city of Khoy, in the north-west of Iran (Fig. 1). The Khoy ophiolite is a remnant of the Neo-Tethys oceanic basin. The Neo-Tethys was a Mesozoic oceanic basin, forming during the Paleozoic to Triassic interval. This event occurred at the stage of closing of the Paleo-Tethys Ocean, which was located between the Afro-Arabic plateau in the south and Eurasia in the north, and its main formation and development occurred during the Cretaceous (Sengor and Yilmaz, 1981; Dilek and Moores, 1990). Structurally, the Khoy ophiolite is related to the southern ophiolite belt of Turkey which extends eastwards to the Mediterranean Sea. The continuation of this belt is located in Iran along with Zagros Thrust, as seen in the Kermanshah and Niriz outcrops: namely, ophiolites of the Zagros suture zone or Bitlis-Zagros ophiolite belt (Sengor and Yilmaz, 1981; Alavi, 1994).

In this research, the geochemistry of the volcanic host rocks of the VMS mineralisation in the Qezil Dash area was investigated to determine their geological/tectonic setting. In this way, the geological environment and the lithostratigraphic position of the sulphide mineralisation may be determined in the volcanic sequence. In the following, an exploration strategy for prospecting for VMS deposits in the Khoy ophiolite can be devised by comparing the tectonic environment formation of VMS mineralisations in the study area with the tectonic setting of well-known Cyprus-type VMS deposits.

\section{ANALYTICAL METHODS AND MATERIALS}

Surface and deep exploration studies have been carried out in the Qezil Dash area for exploration of its volcanogenic mas- 
$\mathrm{T}$ a ble 1

The results of chemical analyses of the samples collected from the Qezil Dash area (analysed for REEs and trace elements)

\begin{tabular}{|c|c|c|c|c|c|c|c|c|}
\hline \multirow{2}{*}{ Sample } & BH3-9 & $\mathrm{BH} 1-4$ & $\mathrm{BH} 1-67$ & $\mathrm{BH} 1-9$ & $\mathrm{BH} 1-87$ & $\mathrm{BH} 1-92$ & $\mathrm{BH} 1-94$ & $\mathrm{BH} 3-36$ \\
\hline & \multicolumn{8}{|c|}{$[\mathrm{ppm}]$} \\
\hline La & 2.94 & 6.41 & 8.43 & 12.87 & 7.44 & 7.46 & 7.18 & 7.28 \\
\hline $\mathrm{Ce}$ & 6.56 & 14.40 & 16.90 & 25.99 & 15.50 & 15.44 & 14.64 & 14.70 \\
\hline $\mathrm{Pr}$ & 0.98 & 1.81 & 2.14 & 3.15 & 1.92 & 2.01 & 1.88 & 1.95 \\
\hline $\mathrm{Nd}$ & 4.32 & 7.75 & 8.88 & 12.27 & 8.38 & 8.31 & 7.89 & 7.84 \\
\hline $\mathrm{Sm}$ & 1.27 & 1.89 & 2.20 & 2.60 & 2.11 & 2.11 & 1.91 & 2.02 \\
\hline $\mathrm{Eu}$ & 0.45 & 0.56 & 0.74 & 0.77 & 0.69 & 0.69 & 0.55 & 0.65 \\
\hline $\mathrm{Gd}$ & 1.65 & 2.21 & 2.37 & 2.74 & 2.74 & 2.49 & 2.19 & 2.24 \\
\hline Dy & 2.07 & 2.45 & 2.50 & 2.83 & 2.84 & 2.84 & 2.45 & 2.46 \\
\hline $\mathrm{Ho}$ & 0.43 & 0.52 & 0.53 & 0.59 & 0.58 & 0.58 & 0.52 & 0.52 \\
\hline $\mathrm{Er}$ & 1.26 & 1.52 & 1.52 & 1.73 & 1.75 & 1.74 & 1.56 & 1.49 \\
\hline $\mathrm{Tm}$ & 0.21 & 0.24 & 0.24 & 0.27 & 0.28 & 0.28 & 0.25 & 0.25 \\
\hline $\mathrm{Yb}$ & 1.23 & 1.58 & 1.59 & 1.73 & 1.72 & 1.73 & 1.59 & 1.46 \\
\hline $\mathrm{Lu}$ & 0.21 & 0.29 & 0.24 & 0.28 & 0.28 & 0.28 & 0.26 & 0.24 \\
\hline $\mathrm{Ti}$ & 2991.2 & 4102.8 & 3282.4 & 3508.8 & 3169.6 & 3220.4 & 3980.8 & 3374.0 \\
\hline $\mathrm{Zr}$ & 39.0 & 58.5 & 49.6 & 61.3 & 36.5 & 43.3 & 56.2 & 44.1 \\
\hline $\mathrm{Nb}$ & 3.9 & 6.3 & 4.1 & 5.9 & 4.5 & 4.7 & 5.4 & 4.0 \\
\hline Th & 4.5 & 7.8 & 12.7 & 1.9 & 11.7 & 8.4 & 9.9 & 12.2 \\
\hline $\mathrm{Ta}$ & 0.72 & 0.44 & 0.37 & 0.18 & 0.67 & 0.74 & 0.22 & 0.18 \\
\hline $\mathrm{Hf}$ & 1.59 & 3.21 & 2.48 & 3.29 & 2.08 & 1.69 & 2.94 & 2.43 \\
\hline $\mathrm{U}$ & 0.87 & 0.10 & 0.29 & 0.63 & 0.2 & 0.1 & 0.1 & 0.1 \\
\hline$Y$ & 11.65 & 14.21 & 14.47 & 16.32 & 17.02 & 17.05 & 14.25 & 14.57 \\
\hline $\mathrm{Cr}$ & 32 & 46 & 96 & 46 & 97 & 101 & 27 & 38 \\
\hline $\mathrm{Ni}$ & 15.90 & 15.90 & 36.3 & 15.90 & 28.2 & 27.7 & 12.1 & 24.0 \\
\hline
\end{tabular}

sive sulphide ore deposit. In this regard, more than 500 samples have been collected from the litho-geochemical sampling grid and from boreholes in the study area. In the present research, 20 samples from volcanic rocks of the Khoy ophiolite were selected for chemical analyses. Chemical analysis was carried out on 12 samples for major oxides and some rare elements and also eight samples were analysed for rare earth elements (REEs) and rare elements. Three of the samples belong to small sub-volcanic bodies which intruded into the volcanic units and are located close to ore-bearing areas, and the rest of the samples were collected from core material of the host rock of sulphide mineralisation. Ten (10) samples were selected for petrographic studies, eight samples for ore microscopy and seven samples for mineralogical studies by X-ray diffraction (XRD) method. Chemical analysis was conducted on the samples at the State Key Laboratory of Geological Processes and Mineral Resources (GPMR) of Wuhan University (Hubei, China). The samples were crushed, reduced in volume, and pulverized to 200 mesh. Geochemical analyses of major oxides were performed by the Inductively Coupled Plasma Emission Spectrometer (ICP-ES) method, and for 25 minor and rare earth elements the inductively coupled plasma mass spectrometer (ICP-MS) method was used. To determine the concentrations of ferrous and ferric iron oxides a wet chemistry method was used on seven samples. In this analysis, the major elements and numbers of trace elements and REEs were measured by using the powder of melted samples with lithium-tetra borate and dissolving in nitric acid.

The detection limit of the measurement for most of the major elements is $0.01 \mathrm{wt} . \%$ and the range of this limit for most of the trace elements with respect to the element type is 0.1 to $0.01 \mathrm{ppm}$. The obtained values for chemical analysis are presented in Tables 1 and 2.

\section{GEOLOGICAL SETTING}

The Khoy ophiolite complex forms an elongate NNW-trending domal structure along the Iran-Turkey border in the northwest of Iran, which covers approximately $3900 \mathrm{~km}^{2}$, being $15-40 \mathrm{~km}$ wide and approximately $110 \mathrm{~km}$ long. The Khoy ophiolite includes the typical rock types of one well-developed ophiolite, with the different types of outcrops in different parts. The main rock units of the area are formed of ultramafic rocks (including harzburgite, dunite, and a little pyroxenite) rodingite dikes, gabbro, diorite, plagiogranite, diabase dikes, basaltic and andesitic lava. The other rock units which accompany the lithology of Khoy area are pelagic sedimentary rocks and radiolarian chert of Upper Cretaceous age and sequences of flysch sedimentary rocks of Paleocene to Lower Eocene age. The upper parts of the Khoy ophiolite are formed of submarine volcanic lavas, which extend widely across the area, outcropping in regions such as Qezil Dash, Qareh Dareh and Aland. As regards texture and structure, these rocks are found in two different facies: pillow lavas (Aland volcanic unit) and massive sheet lavas (Quezil Dash volcanic unit). The pillow lavas are of MOR-type basaltic type while the massive sheet lavas are of basaltic, andesitic and andesitic basalt compositions (Imamalipour, 2001; Hassanipak and Ghazi, 2000). The upper levels of the volcanic rocks, enclose pink pelagic limestone lenses, of late 
The results of chemical analyses for samples collected from the Qezil Dash area (analysed for major oxides and some of the trace elements)

\begin{tabular}{|c|c|c|c|c|c|c|c|c|c|c|c|c|}
\hline Sample & SP-1 & SP2 & SP3 & SP-4 & SP-6 & SP-7 & SP-8 & LG-19 & LG-12 & QZS-1 & QZS-2 & QZS-3 \\
\hline \multicolumn{13}{|c|}{ [wt.\%] } \\
\hline $\mathrm{SiO}_{2}$ & 46.01 & 59.90 & 51.83 & 53.85 & 50.76 & 60.60 & 56.66 & 46.46 & 46.39 & 44.65 & 50.68 & 54.01 \\
\hline $\mathrm{Al}_{2} \mathrm{O}_{3}$ & 21.01 & 15.00 & 16.02 & 16.35 & 16.28 & 15.54 & 15.76 & 13.83 & 14.73 & 19.35 & 19.72 & 16.33 \\
\hline $\mathrm{Fe}_{2} \mathrm{O}_{3}$ & 4.57 & 3.21 & 4.60 & 5.25 & 3.64 & 2.47 & 3.78 & 16.22 & 15.06 & 13.12 & 11.24 & 8.29 \\
\hline $\mathrm{FeO}$ & 5.13 & 3.12 & 4.38 & 1.02 & 4.68 & 3.36 & 3.54 & - & - & - & - & -- \\
\hline $\mathrm{CaO}$ & 10.98 & 3.22 & 8.53 & 6.07 & 5.89 & 3.69 & 6.04 & 10.38 & 8.43 & 10.83 & 5.80 & 8.34 \\
\hline $\mathrm{Na}_{2} \mathrm{O}$ & 2.58 & 5.24 & 2.26 & 7.40 & 4.28 & 4.10 & 3.22 & 0.07 & 0.99 & 2.41 & 2.78 & 3.75 \\
\hline $\mathrm{K}_{2} \mathrm{O}$ & 0.38 & 0.66 & 0.37 & 0.58 & 0.48 & 1.11 & 0.54 & 1.77 & 3.68 & 1.00 & 0.11 & 0.28 \\
\hline $\mathrm{MgO}$ & 3.83 & 3.21 & 5.70 & 3.11 & 5.28 & 3.43 & 4.66 & 0.27 & 1.44 & 4.10 & 5.05 & 5.87 \\
\hline $\mathrm{TiO}_{2}$ & 0.88 & 0.65 & 0.64 & 0.58 & 0.68 & 0.46 & 0.63 & 0.59 & 0.68 & 0.93 & 0.81 & 0.72 \\
\hline $\mathrm{PO}_{5}$ & 0.08 & 0.22 & 0.10 & 0.13 & 0.14 & 0.09 & 0.14 & 0.18 & 0.11 & 0.04 & 0.075 & 0.174 \\
\hline L.O.I & 4.55 & 5.56 & 5.57 & 5.66 & 7.89 & 5.19 & 5.03 & 4.96 & 5.60 & 3.57 & 3.73 & 2.23 \\
\hline \multicolumn{13}{|c|}{ [ppm] } \\
\hline $\mathrm{Cr}$ & 27.3 & 20.2 & 171.2 & 37.7 & 54.0 & 35.8 & 57.5 & 92 & 28 & 215 & 449 & 637 \\
\hline $\mathrm{Ni}$ & 12.5 & 4.1 & 33.6 & 12.9 & 17.1 & 11.6 & 12.4 & 24 & 25 & 18 & 59 & 57 \\
\hline $\mathrm{Ti}$ & 5270 & 3900 & 3840 & 3480 & 4080 & 2760 & 3780 & 3537 & 4076 & 5573 & 4856 & 4316 \\
\hline $\mathrm{Zr}$ & 31.7 & 114.6 & 64.5 & 98.5 & 74.6 & 88.5 & 91.8 & 29 & 34 & 33 & 73 & 96 \\
\hline$Y$ & 8.5 & 25.4 & 15.2 & 19.0 & 16.2 & 14.3 & 16.6 & - & - & 41 & 38 & 61 \\
\hline $\mathrm{Sr}$ & 572 & 138 & 290 & 188 & 423 & 205 & 307 & 251 & 184 & 660 & 683 & 448 \\
\hline $\mathrm{Nb}$ & 4.3 & 8.0 & 5.2 & 7.5 & 6.2 & 4.1 & 6.1 & - & - & 43.0 & 30.0 & 9.0 \\
\hline $\mathrm{Rb}$ & 2 & 7.7 & 2.7 & 4.5 & 3.5 & 13.4 & 6.1 & 6 & 19 & 5 & 9 & 4 \\
\hline
\end{tabular}

Campanian age (Geological Survey and Mineral Explorations of Iran, 1997). In most areas basaltic pillow lavas adjoin the pelagic sedimentary rocks with a transitional contact. The submarine volcanic facies of the Khoy ophiolite has been recognized as hosting VMS mineralisation (Imamalipour and Masoudi, 1995).

In the Qezil Dash area, the submarine volcanic rocks contain sulphide ore-bearing zones. The thickness of the submarine volcanic rocks is about 1200 metres. To the north, pelagic sedimentary rocks including limestone and shale conformably overlie the volcanic rocks; the passage between them is transitional and consists of a volcanic-sedimentary unit. These lithological units have an almost east-west strike with a $45^{\circ}$ dip towards the north; a geological cross-section of the study area is depicted in Figure 2 (Imamalipour, 2001).

\section{RESULTS AND DISCUSSION}

\section{MINERALISATION AND ALTERATION}

The Qezil Dash volcanic unit are hosts to sulphide mineralisation. Although based on the host rock characteristics and tectonic setting of mineralisation, these deposits can be described as of Cyprus-type VMS mineralisation, though in terms of tonnage and grade they are not as large as in well-known examples of Cyprus-type VMS deposits such as Troodos (Oman) and Semail (Oman).

Based on field and microscope observations, and also on X-ray mineralogical study, the VMS ore mineralisations in the Qezil Dash district are mostly found associated with chlorite, quartz, epidote, calcite and sericite gangues. Quartz occurs either as secondary disseminated grains associated with ore minerals, veins and vein stockworks which are irregularly distributed in the mineralized bodies. Ore mineral assemblages include pyrite, chalcopyrite, sphalerite, and covellite. Azurite and malachite are present in the oxidized zone.

The ore-bearing zones consist of two major parts; a concordant lenticular semi-massive to massive sulphide ore body which is underlain by a discordant stringer zone (stockwork vein system) and associated alteration halo. The later is better developed (Fig. 3A). These veins and veinlets cross-cut the host rock and have an opposite dip to the massive sulphide lenses. In the stockwork zones, quartz-sulphide alteration is prevalent, but the pervasive alteration of the volcanic host rock is chlorite-quartz-sericite. The amounts of silica and sericite minerals increase in the stringer zones. The dominant alteration associated with the VMS mineralisation of the Qezil Dash area is chloritization, which has extensively affected the host rock of ore-bearing zones (Fig. 3B).

Surface processes of weathering and oxidation of pyrite and other sulphides to form Fe oxyhydroxides plus sulphuric acid have led to the formation of gossan above the ore-bearing zones. Hydrated iron oxide minerals including limonite and goethite are the abundant phases in the oxidized zone. The other important associated minerals are jarosite, silica, gypsum, malachite, azurite and clay minerals. According to the abundant presence of secondary iron hydroxides, the gossans can be clearly identified by their bright brown color (Fig. 3B). The thickness of the weathered zone varies from 11 to 32 metres with an average thickness of about 18 metres based on data obtained from core samples (Imamalipour, 2001).

The mineral composition of the altered and mineralized rocks was determined by using X-ray diffraction. The mineral assemblages of selected samples from different zones are given in Table 3. 


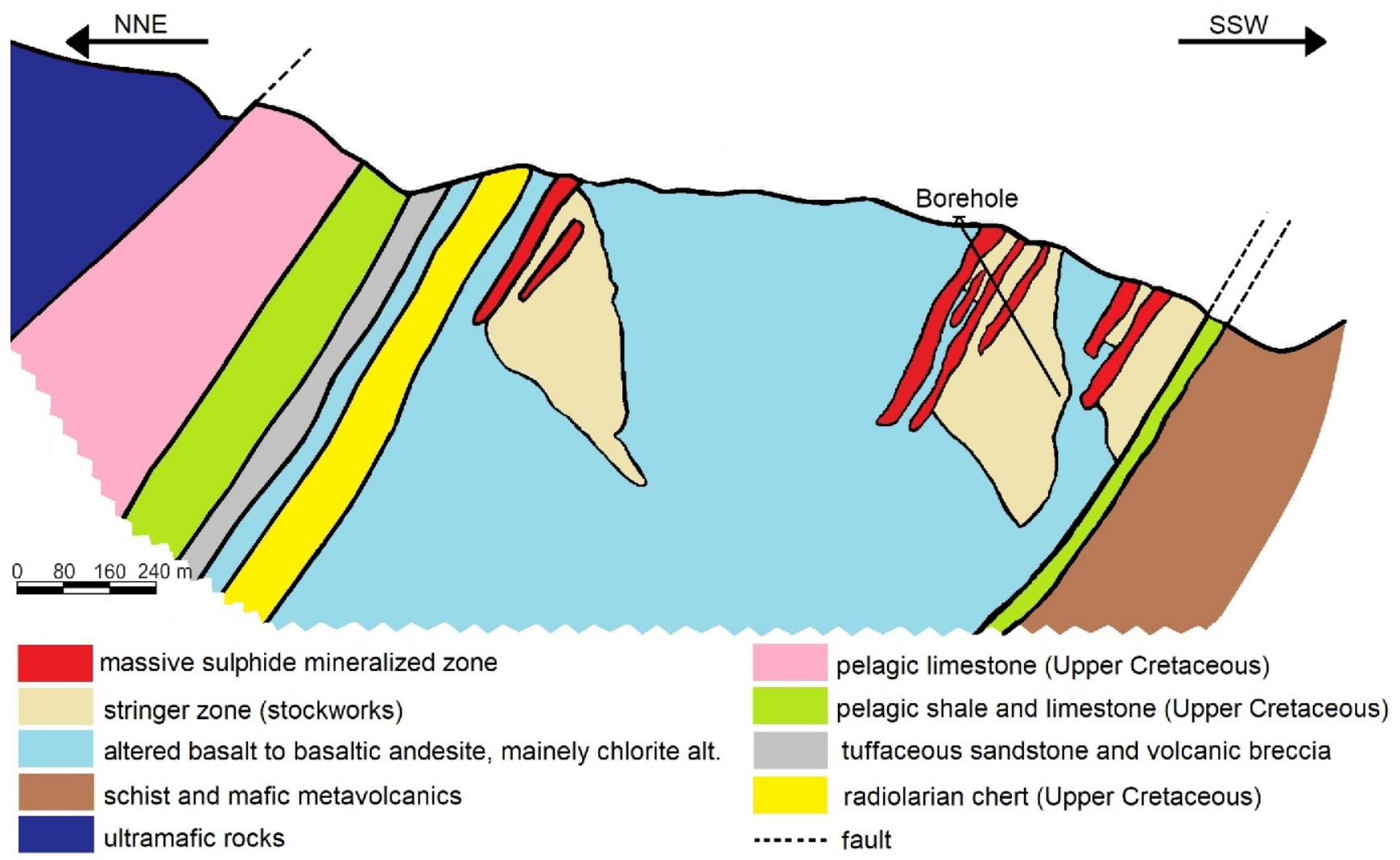

Fig. 2. The geological profile of the Qezil Dash area along a NNE-SSW trend
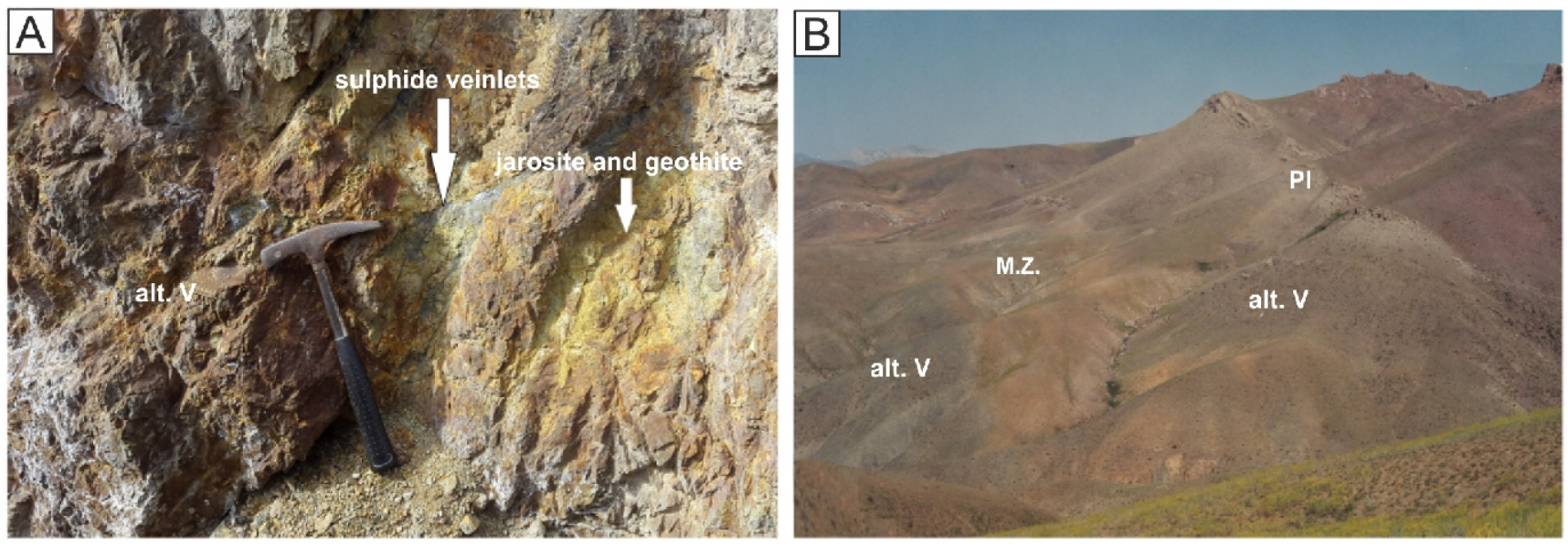

Fig. 3A - sulphide veinlets within altered volcanic rock (alt. V), goethite and jarosite are abundant minerals in the oxidized zone; B - a mineralized zone (M.Z.) within the Qezil Dash unit, its gossan can be clearly identified by its bright brown colour, pelagic sedimentary rocks (PI) conformably overlie the Qezil Dash unit

\section{PETROGRAPHY}

Based on petrographic study, the mineral composition of the volcanic host rocks is simple. In most of these rocks, plagioclase is the dominant mineral, with an abundance of about $80 \%$ of the total rock volume (Fig. 4A, B). Clinopyroxene (augite), amphibole and quartz are other constituent minerals which total some 5-30 vol.\%. Ferromagnesian minerals are pervasively altered to alteration products such as chlorite, epidote, calcite, and sericite. Quartz is observed in the matrix of some specimens as anhedral and as a fine-grained secondary mineral. In general, the matrix in most of these rocks is microlithic and fine-grained, comprising aggregates of epidote, chlorite, and quartz. These rocks have porphyritic, microporphyritic, microlithic, glomeroporphyritic, amygdaloidal and in some cases brecciated textures (Fig. 4C, D).

In some instances, the lithic fragmental materials are seen in an altered matrix (Fig. 4F). Fragmental material is derived from autobrecciation, quench fragmentation and pyroclast fragmentation. This process causes non-explosive fragmentation of crystallized lava. Autobrecciation is common in the upper portions, along the edges of and inside submarine lavas (Cas, 1992). 
Mineral composition of altered and mineralized rocks from different zones obtained by X-ray diffraction (XRD)

\begin{tabular}{|l|c|c|c|}
\hline Sample & Major minerals & Minor minerals & Zone/rock type \\
\hline $\mathrm{BH} 1-03$ & chlorite, quartz, epidote, pyrite & malachite, chalcopyrite & deep level of the oxidized zone \\
\hline $\mathrm{KH}-11$ & chlorite, quartz, epidote, pyrite & bornite, sericite & hypogene stockwork zone \\
\hline $\mathrm{BH} 1-11$ & quartz, epidote, chlorite & pyrite, sericite, gypsum & hypogene stockwork zone \\
\hline $\mathrm{BH} 1-05$ & chlorite, albite, epidote & quartz, pyrite, gypsum, calcite & oxidized zone \\
\hline $\mathrm{BH}$-07 & chlorite, albite, quartz & epidote, pyrite, calcite & altered volcanic host rock \\
\hline $\mathrm{BH} 1-09$ & chlorite, albite, epidote, quartz & pyrite, sericite, calcite & hypogene stockwork zone \\
\hline T5-04 & chlorite, quartz, albite & epidote, malachite & oxidized zone \\
\hline T2-08 & quartz, gypsum, goethite & chlorite, epidote, calcite, malachite & massive ore (oxidized zone) \\
\hline
\end{tabular}

The volcanic rocks are extensively altered and the primary volcanic textures of these rocks are usually overprinted during fluid/rock interactions. The most prominent mineralogical features of these rocks are the abundance of secondary minerals such as epidote, chlorite, and calcite as anhedral form, disseminations, or aggregates in the matrix, amygdales, veinlets, and pseudomorphs of primary minerals. Chlorite sometimes fills the amygdales (Fig. 4D). Epidote is more abundant than chlorite, and in some cases, more than $60 \%$ of the rock consists of epidote (Fig. 4F). Petrographically, these rocks can be named altered andesite to altered basaltic andesite, and they also can be considered as of tholeiitic affiliation.

Chlorite group minerals have a wide range of chemical compositions which reflect the physicochemical conditions of their crystallization. The solid solution (cationic substitution) model in the crystal lattice of chlorite was satisfactorily used in the estimation of its formation temperature in different geological environments such as ore deposits, low-degree metamorphism, hydrothermal alteration and diagenesis (Cathelineau, 1988; Imamalipour and Rasa, 2009). Based on the chlorite geothermometry method, the formation temperature ranges for different parts of orebody varied from 318 to $368^{\circ} \mathrm{C}$ while the range for unmineralized altered rocks varied from 202 to $210^{\circ} \mathrm{C}$ (Imamalipour and Rasa, 2009).

The ore paragenesis is very simple and is characterized by a major-mineral assemblage dominated by pyrite along with variable but subordinate amounts of chalcopyrite, bornite, and sphalerite. Sphalerite is present in trace amounts, generally as small inclusions in major sulphide minerals (Fig. 5A). Pyrite occurred either as euhedral to subhedral disseminated grains or as veins and stockworks irregularly distributed in the mineralized bodies (Fig. 5B). Locally it is extensively shattered, the fractures being infilled with chalcopyrite (Fig. 5C). Chalcopyrite also occurs as an independent phase of pyrite (Fig. 5D). Covellite is also present in trace amounts and is derived from chalcopyrite alteration (Fig. 5E). Based on data obtained from core samples it only exists in the passage of the oxidation zone to the primary sulphide zone (Imamalipour, 2001). All the sulphide minerals are altered to secondary oxidation products in the oxidized zone. Pyrite is altered to Fe oxyhydroxides which gradually crystallizes to goethite (Fig. $5 \mathrm{~F}$ ).

\section{GEOCHEMISTRY}

As noted, two types of submarine volcanic rock are found in the Khoy ophiolite, known as Aland volcanic unit and Qezil Dash volcanic unit. Among these rock types, submarine lavas of the Qezil Dash volcanic unit are host to sulphide mineralisation. Therefore, recognizing the geochemical nature of this host rock and determining the tectonic setting of its formation is significant for determining the type of mineralisation and its exploration.

Because of the effects of hydrothermal alteration, the data of major oxides have not been used to determine the tectonic setting or in geochemical studies. Hydrothermal alteration causes redistribution of mobile elements. For example, the irregular distribution of the Qezil Dash samples on the AFM triangular diagram (Irvine and Barragar, 1971) and the plotting of some samples in the calc-alkaline domain is interpreted as reflecting such hydrothermal change (Fig. 6A). Thus, REEs and trace elements, especially high field strength elements (HFSE) such as $\mathrm{Zr}, \mathrm{Y}, \mathrm{Ti}, \mathrm{Hf}$, and $\mathrm{Nb}$ were preferentially used in the geochemical investigations. These elements are recognized as incompatible elements, which are geochemically immobile during weathering and hydrothermal alteration processes (Desmons and Beccaluva, 1983; MacLean and Barrett, 1993; Rollinson, 1993; Kurtz et al., 2000).

The position of data from samples collected from the Qezil Dash volcanic rocks in the $\mathrm{Nb} / \mathrm{Y}$ versus $\mathrm{Zr} / \mathrm{TiO}{ }_{2}$ diagrams is consistent with the petrographic data: in Figure 6B these samples plotted in the domain of andesite, andesitic basalt, and basalt. The $\mathrm{Cr}$ values range from 14.5 to $145 \mathrm{ppm}$ for the Qezil Dash tholeiitic lavas. In comparison with abyssal tholeiites, these samples plotted in the LKT (low-potassium tholeiitic) lava domain. The range of $\mathrm{Cr}$ values in abyssal tholeiite vary from 140 to 480 ppm (Wilson, 2007). Ni values show a similar pattern to the $\mathrm{Cr}$ values for the Qezil Dash volcanic rocks: they range from 40 to $40.4 \mathrm{ppm}$, while the range of $\mathrm{Ni}$ concentrations in abyssal tholeiites varies from 55 to $380 \mathrm{ppm}$. In general, island arc basalts (IAB) contain low concentrations of $\mathrm{Ni}$ (Wilson, 2007). The average content of $\mathrm{K}_{2} \mathrm{O}$ and $\mathrm{Rb}$ in the volcanic rocks of Qezil Dash is $0.62 \%$ and $7.7 \mathrm{ppm}$ respectively, which is comparable to those of island arc tholeiites (IAT; Wilson, 2007). The average contents of $Y$ and $Z r$ (respectively, 15.6 and 59 ppm) are within the range of IAT (27 ppm and $51 \mathrm{ppm}$, respectively; Wilson, 2007). These rocks are also known to have low values of $\mathrm{Zr} / \mathrm{Hf}$ (average 20) and $\mathrm{Nb} / \mathrm{Ta}$ (average 11) ratios.

The distribution and concentration of $\mathrm{Ti}$ are recognized as geochemical criteria in the determination of ophiolite lava type. As represented by Beccaluva et al. (1983) and Beccaluva (1995) ophiolite lavas based on their Ti content are categorized in three major types, including high-Ti basalt (MORB affinity), low-Ti basalt (IAT affinity) and very low Ti basalt (boninites).

The $\mathrm{TiO}_{2}$ values range from 0.76 to $0.30 \% \mathrm{ppm}$ for the Qezil Dash lavas, the average value being $0.57 \%$. The positions of the Qezil Dash lava samples are shown in the diagrams of Ti/Cr versus Ni (Fig. 7A; Beccaluva et al., 1983) and $\mathrm{Ti}$ versus $\mathrm{Cr}$ (Fig. 7B; Pearce and Cann, 1973). Being the host rock of the 

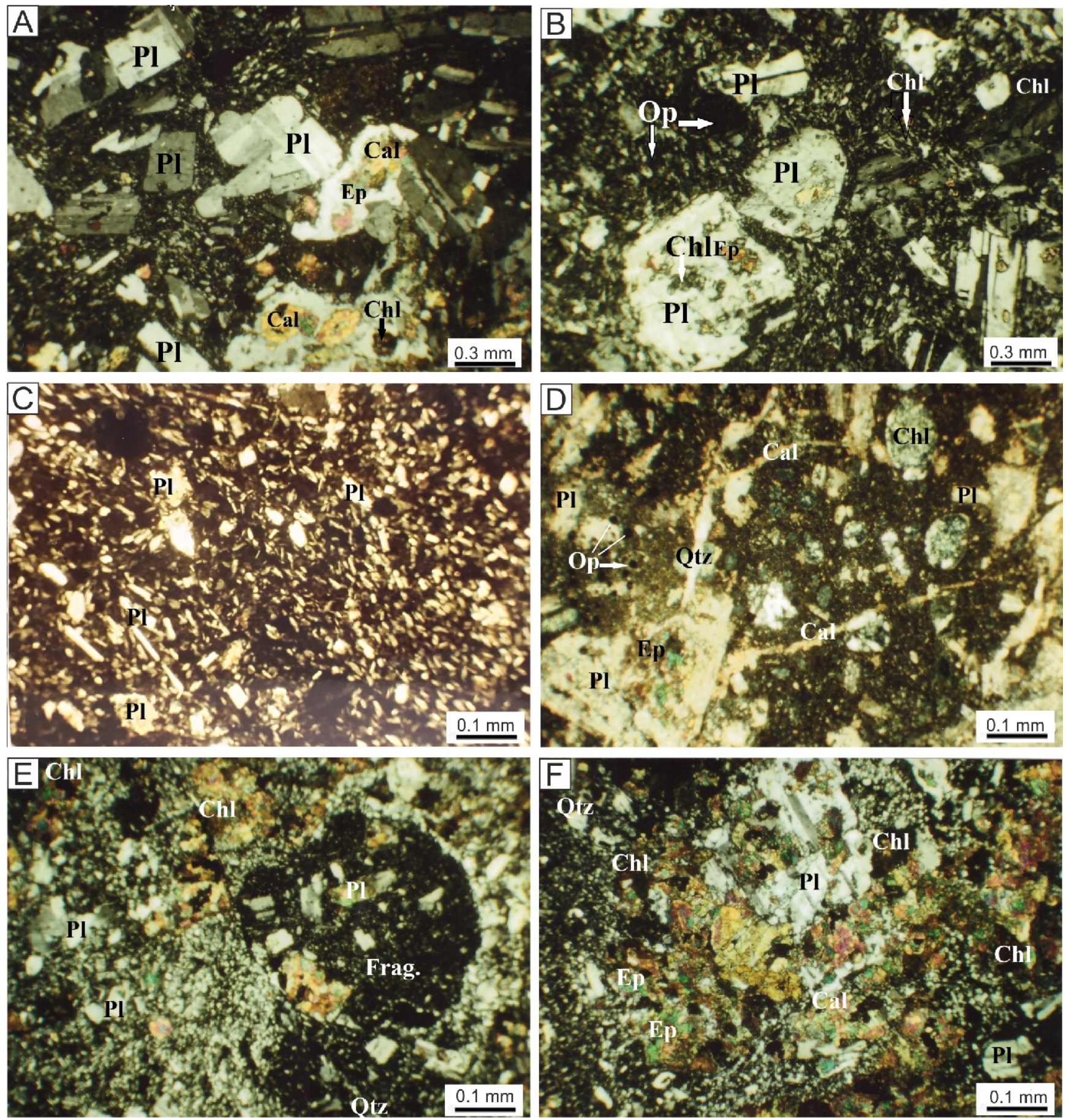

Fig. 4. Microphotographs of volcanic rocks as the host rock of the volcanogenic massive sulphide deposit

A, B - porphyritic texture, plagioclase (PI) is the dominant mineral which is present as phenocrysts and also as lath-shaped microlites (PPI light); C - trachytoid texture, in which the microlites of plagioclase in the groundmass have a subparallel alignment (PPI light); D - amygdaloidal texture in andesitic rocks with chlorite, quartz and secondary veins of calcite (PPI light); $\mathbf{E}$ - lithic fragments within an altered matrix, indicating autobrecciation; $\mathbf{F}$ - extensive alteration of primary minerals and the formation of epidote, chlorite, quartz and calcite (PPI light); Cal - calcite, Chl - chlorite, Ep - epidote, Frag. - lithic fragments, Op - opaque mineral, PI - plagioclase, Qtz - quartz; abbreviations after Whitney and Evans (2010) 

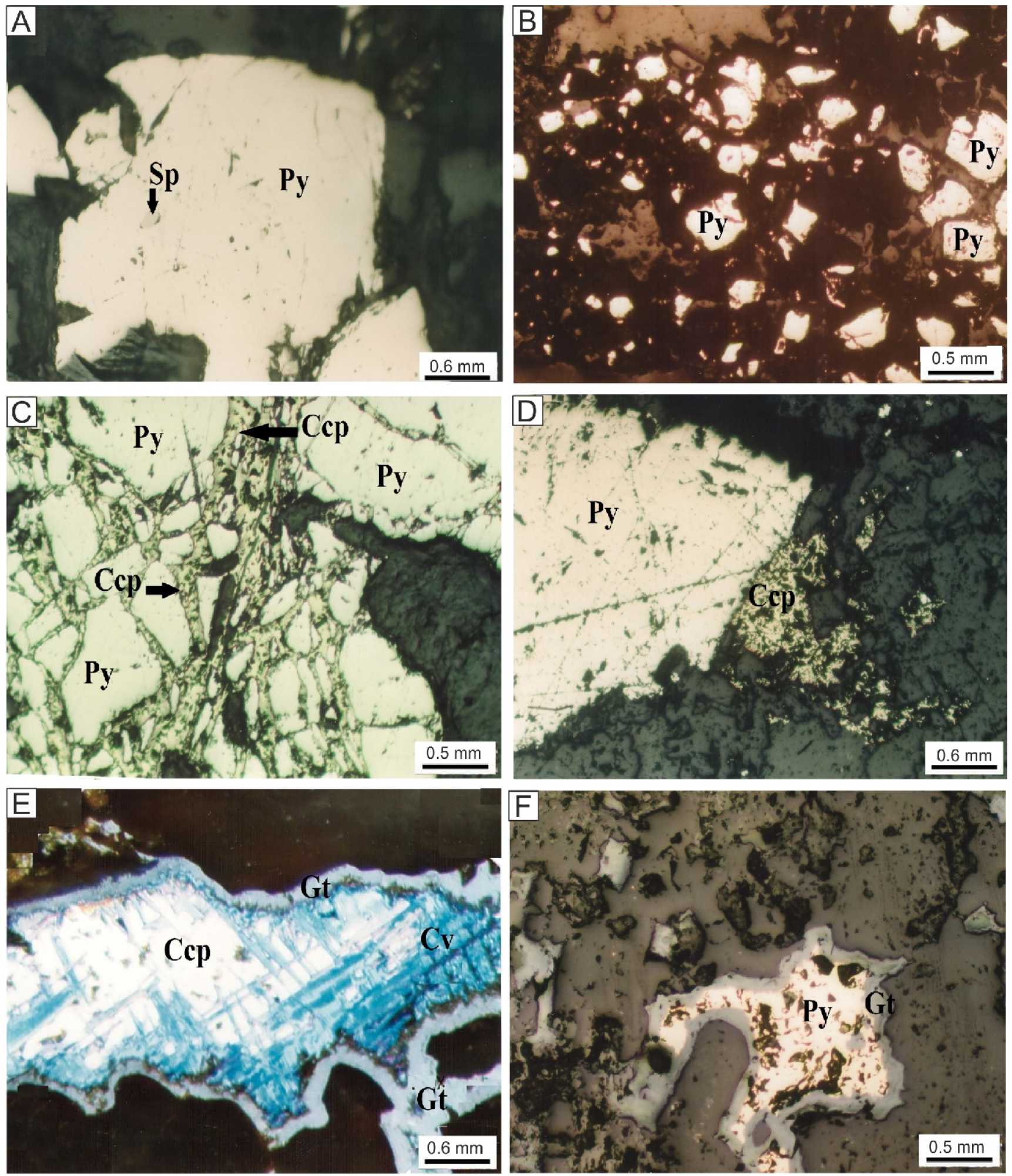

Fig. 5. Reflected light microscope images of the ores investigated from the study area

A - a small inclusion of sphalerite within a large anhedral pyrite; B - disseminated euhedral to subhedral pyrite; C - fractures of pyrite are infilled with chalcopyrite; D - chalcopyrite as an independent phase along with pyrite; $\mathbf{E}$ - chalcopyrite alteration to covellite along cleavages and microfractures, as well as alteration of chalcopyrite to goethite from the margin in the oxidation zone; $\mathbf{F}-$ development of alteration of pyrite to iron hydroxides from its margin in the oxidation zone; $\mathrm{Ccp}$ - chalcopyrite, $\mathrm{Cv}$ - covellite, Gt - goethite, Py - pyrite, Sp - sphalerite; abbreviations after Whitney and Evans (2010) 

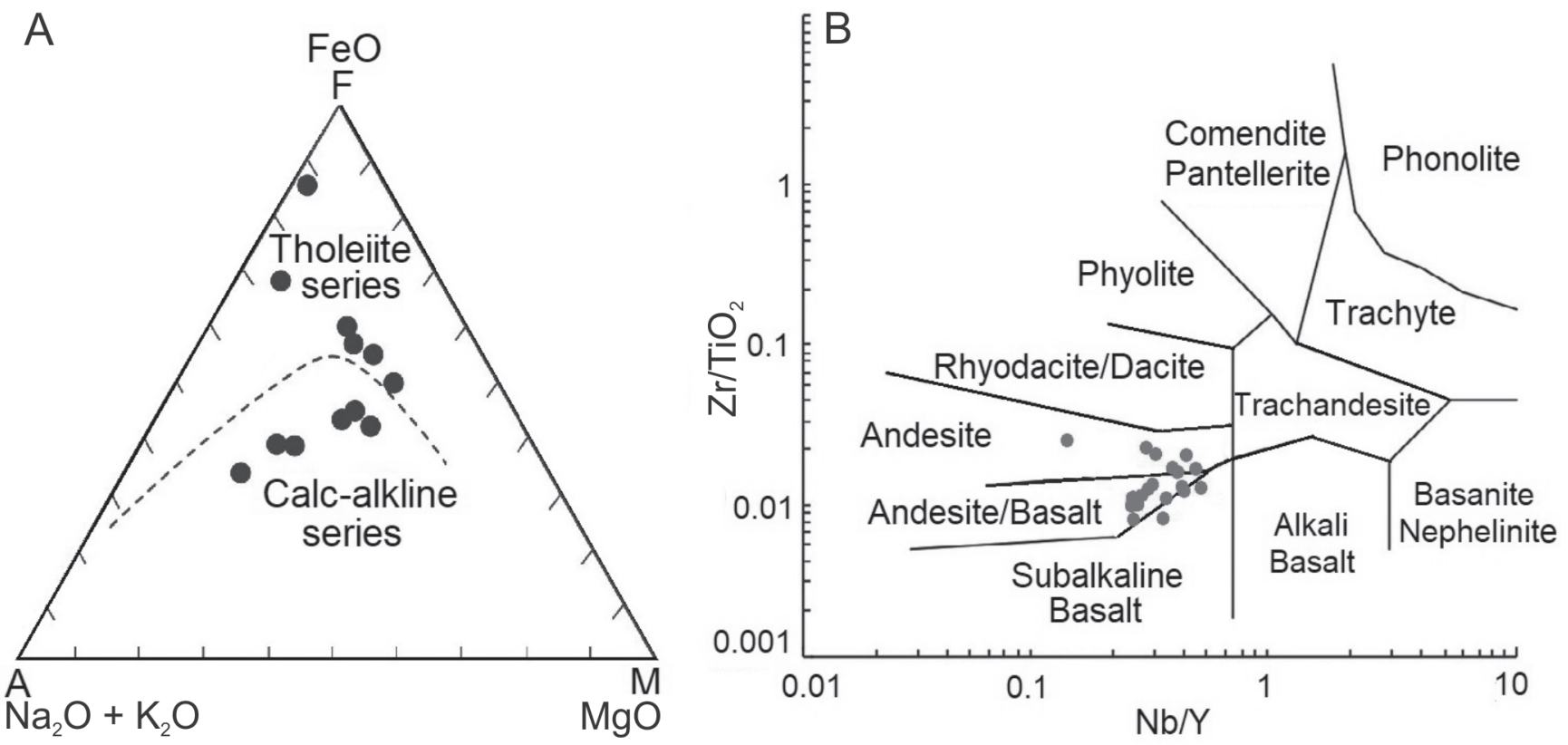

Fig. 6. The position of samples which belong to the Qezil Dash volcanic rocks (the host rock of VMS deposit) for the diagram of $\mathrm{AFM}(\mathrm{A})$ and $\mathrm{Nb} / \mathrm{Y}(\mathrm{B})$ versus $\mathrm{Zr}_{\mathrm{TiO}}$ ratio (Winchester and Floyd, 1977)

A

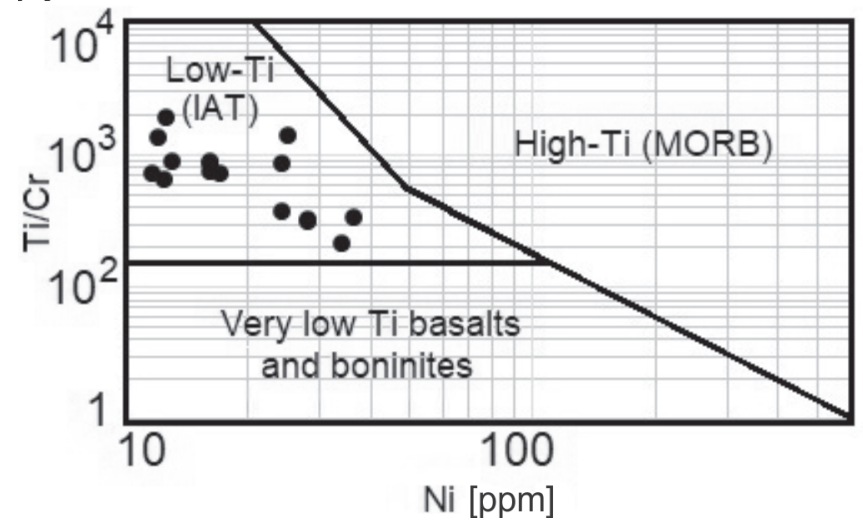

B

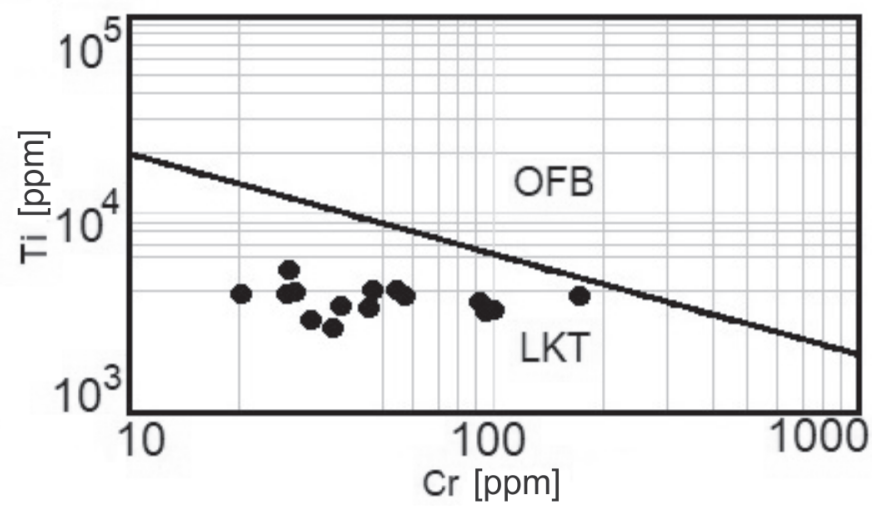

Fig. 7. The position of Qezil Dash volcanic lava samples in the diagrams

A - Ti/Cr versus Ni ratio (Beccaluva et al., 1983), IAT - island arc tholeiites, MORB - mid-ocean ridge basalts; B - Ti versus Cr ratio (Beccaluva, 1995; Pearce, 1996), LKT - low-potassium tholeiites, OFB - ocean-floor basalts

VMS mineralisation, they are of LKT type. Furthermore, the Ti versus Zr discriminant diagram (Fig. 8A; Pearce, 1996) and the triangular diagram of $\mathrm{Hf}-\mathrm{Th}-\mathrm{Nb}$ (Fig. 8B) also indicated the same results, consistent with the formation of the tholeiitic volcanic rocks in an island arc tectonic setting.

The REE spider diagrams of the Qezil Dash (normalized to chondrite) volcanic rocks show that these rocks plot in the island arc tholeiitic compositional domain (Fig. 9A), and the REE contents are distinct from N-MORB values. For example, the average value of $\mathrm{Yb}$ for these rocks is $1.58 \mathrm{ppm}$, while its value for N-MORB is 3.05 ppm (Sun and McDonough, 1989).

Considering Figure 9B the REE values in the Qezil Dash rocks are 10 to 20 times higher than the chondrite values. This pattern can also be recognized based on LREE enrichment, such that the average value of $\mathrm{La} / \mathrm{Sm}$ in the samples analysed was 2.05 . The spider diagram of rare and incompatible ele- ments of the Qezil Dash volcanic rocks normalized to chondrite composition are shown in Figure 9B. For better comparison, the normalized patterns of IAT, E-MORB and OIB series (data from Sun, 1982) are also illustrated in Figure 9. These diagrams represent the severe depletion of HFSE elements (such as $\mathrm{Y}, \mathrm{Nb}$, $\mathrm{Zr}$, and $\mathrm{Hf}$ ), one of the most important geochemical features of the Qezil Dash volcanic rocks. Furthermore, these rocks show a selective enrichment in terms of LILEs (such as $\mathrm{Rb}, \mathrm{Ba}, \mathrm{Th}$, and K). Such a distribution of trace elements has been accepted as an indicator of mafic magmas generated in supra-subduction zone settings (SSZ; Pearce et al., 1984). According to Figure 9B, the pattern of incompatible elements of Qezil Dash lava is slightly higher than in the typical IAT pattern. It seems that the irregular dispersion of elements such as $\mathrm{Ba}, \mathrm{K}$, $\mathrm{Rb}$, and $\mathrm{Th}$ is associated with hydrothermal alteration. 


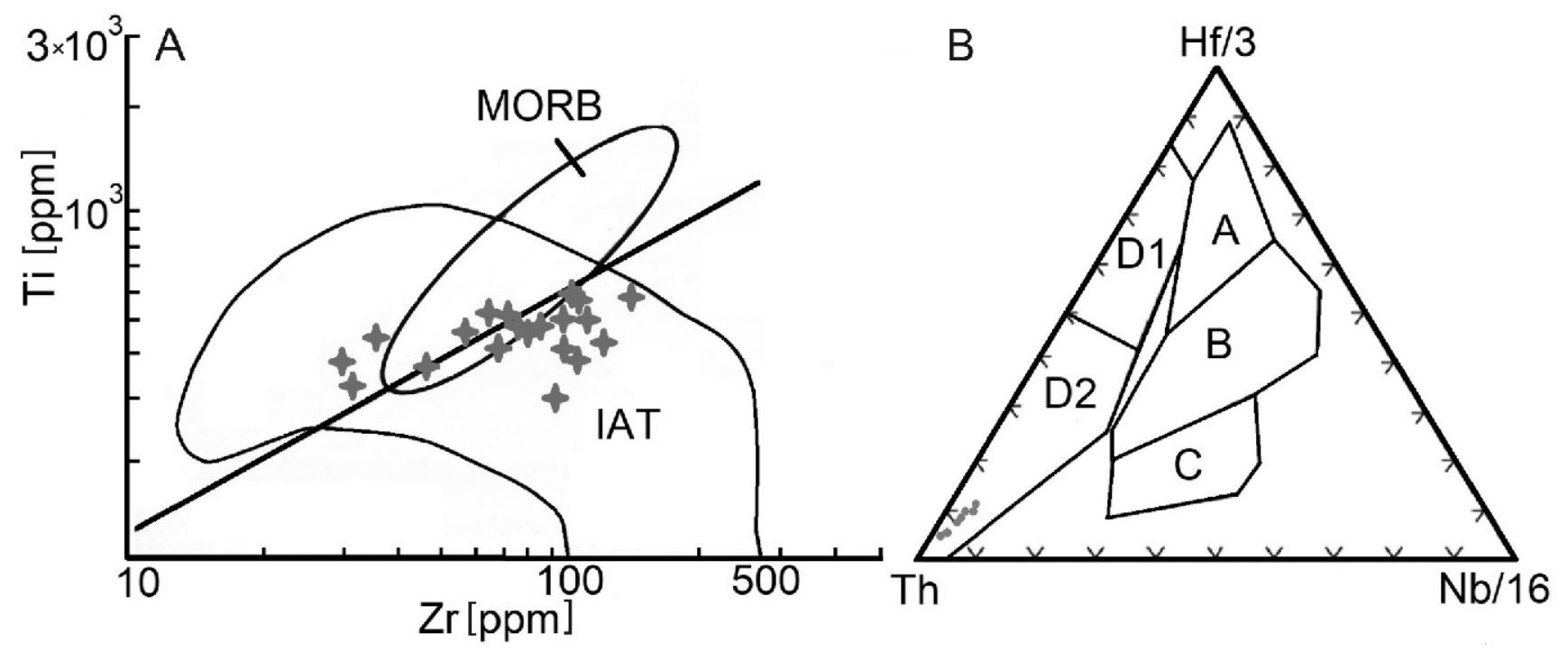

Fig. 8. The position of volcanic lava samples from the Qezil Dash area in the diagrams

A - Ti versus Zr ratio (Pearce et al., 1981), explanations as in Figure 7; B - Hf-Th-Nb triangular diagram: A - N-MORB ("normal" mid-ocean ridge basalts), B - E-MORB ("enriched" mid-ocean ridge basalts), C - OIB (ocean-island basalts, rift), D1 - island arc tholeiites, D2 - calc-alkali basalts (Wood et al., 1980)

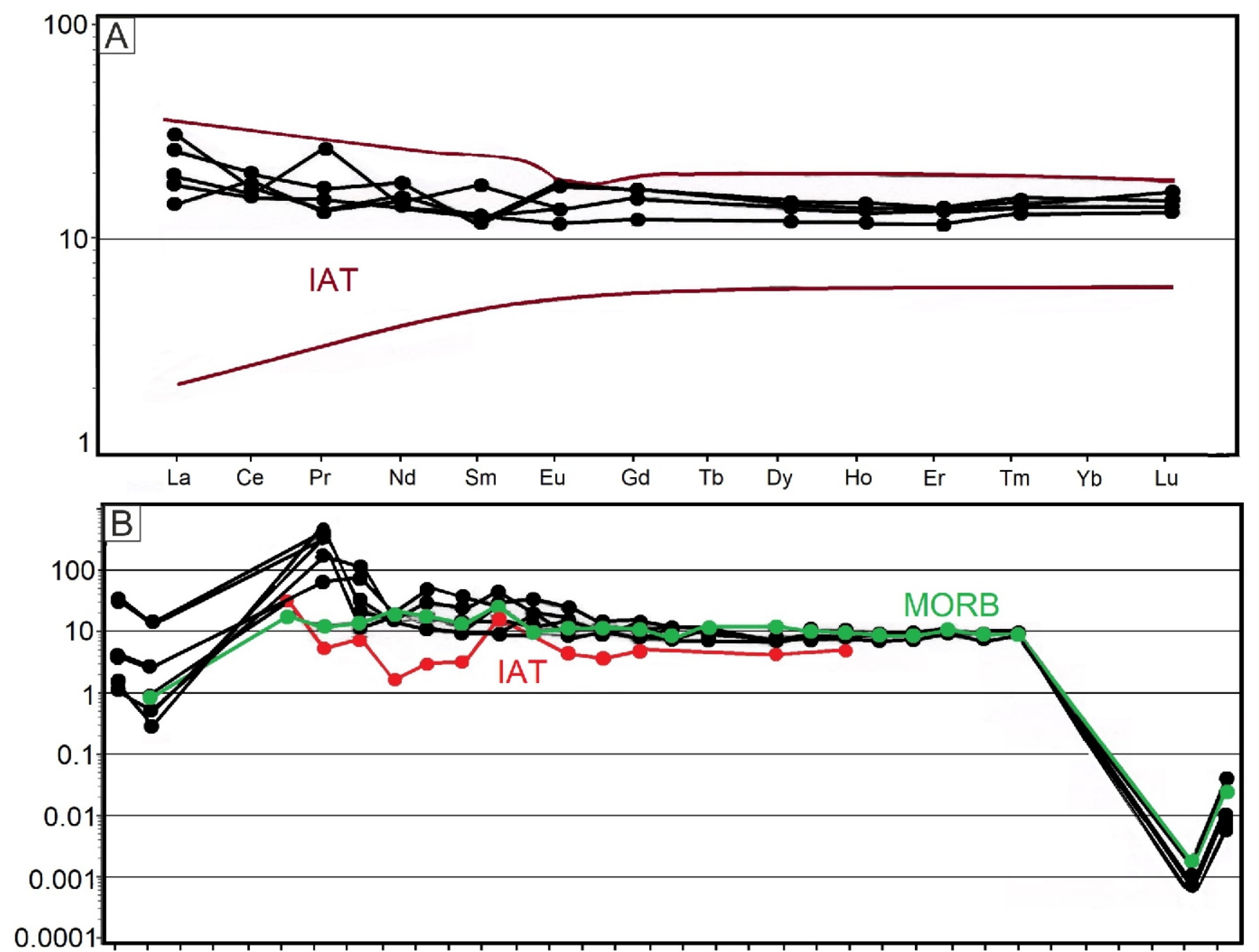

Li K Rb Cs Ti Pb Ba Th U Nb La Cs Si Pt Nd Zr Sm Eu Gd Tb Ti Dy Y Ho Er Tm Yb Lu Sc V Zn Cu Ni Ct

Fig. 9. The distribution pattern: A - rare earth elements (normalized to chondrite); B - incompatible elements (normalized to chondrite) in the tholeiitic lavas of the Qezil Dash area (Wood, 1980; Alabaster et al., 1982; Sun, 1982) 

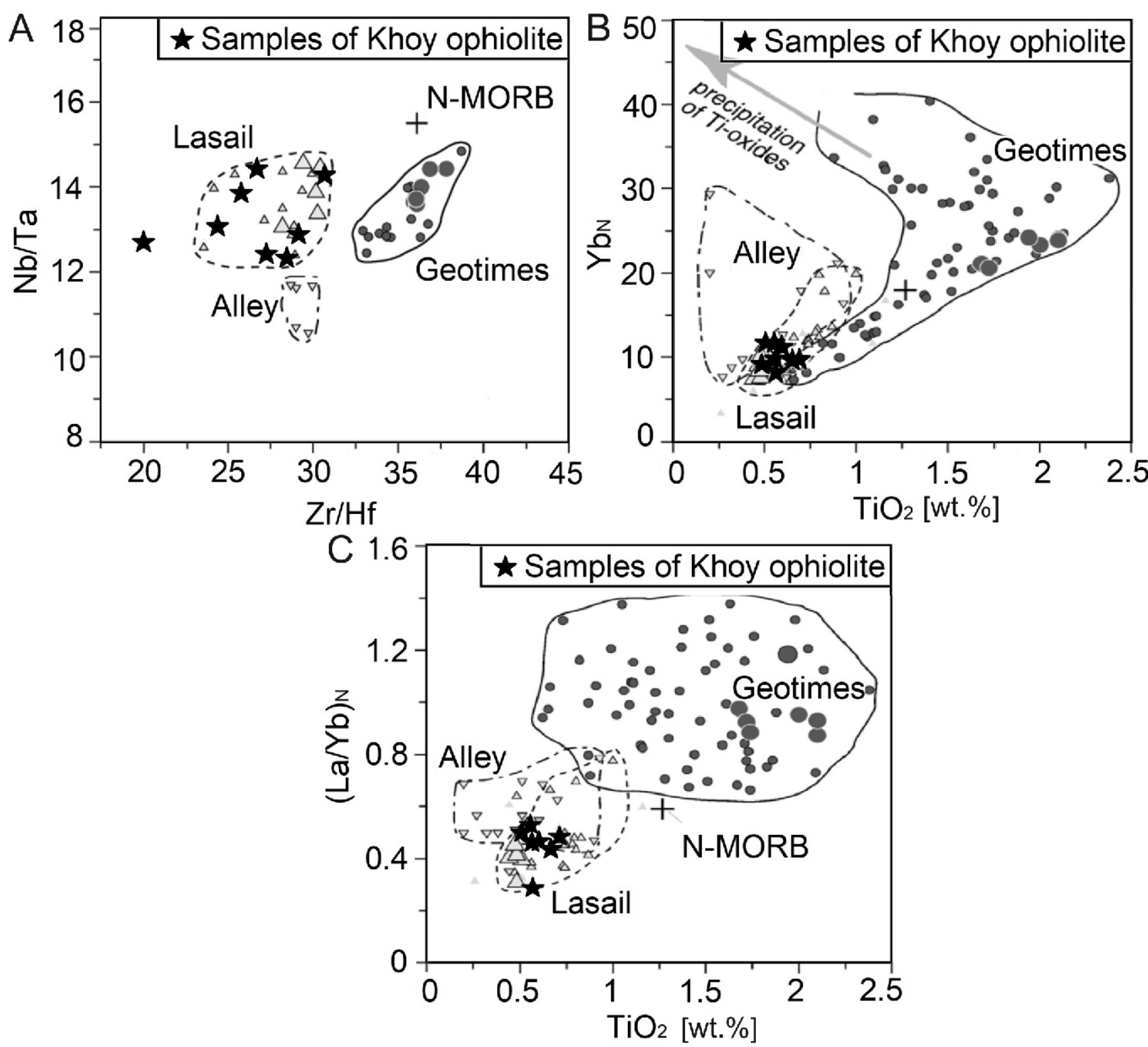

Fig. 10. Plots of the Qezil Dash volcanic samples on discriminant diagrams including: $\mathrm{A}-\mathrm{Nb} / \mathrm{Ta}$ versus $\mathrm{Zr} / \mathrm{Hf}$; $\mathrm{B}-\mathrm{Yb}_{\mathrm{N}}$ versus $\mathrm{TiO}_{2}$ (wt.\%); C - (La/Yb) $)_{\mathrm{N}}$ versus $\mathrm{TiO}_{2}$ (wt.\%)

Diagrams and compositional fields of Oman ophiolite volcanic rocks are from Godard et al. (2006); normalizing values are taken from (Sun and McDonough, 1989); the Qezil Dash lava samples (asterisks) plot in the domain of the Lasail lavas in these diagrams

COMPARISON WITH KNOWN VMS DEPOSITS (CYPRUS-TYPE)

Although the sulphide mineralisation of the Qezil Dash area is classified as a Cyprus-type VMS deposit, it has some dissimilarities with known Cyprus-type deposits. The significant differences between the Qezil Dash sulphide deposits in comparison with the Cyprus area (such as the Agrokipia deposit) and the Oman area (such as the Lasail and Bayda deposits) are in their stratigraphic position as well as the petrological composition of their host rocks. The magma development of the ophiolites of Khoy, Oman, and Cyprus (Troodos) is similar. The volcanic sequence of the Khoy ophiolite is comparable to the volcanic sequence of the Oman ophiolite.

In the Oman ophiolite, three volcanic episodes were distinguished according to the petrology and geochemistry of the extrusive rocks (Godard et al., 2006). The magmatic sequences are separated from each other by more or less continuous layers of pelagic deposits (Pearce et al., 1981; Alabaster et al., 1982; Ernewein et al., 1988). The first two volcanic episodes include the largest volume of erupted lavas (more than $95 \%$, Nicolas et al., 2000). Both of these extrusive lavas are tholeiitic affinity, associated with the early stages of ophiolite formation (Godard et al., 2006). According to previous researchers, the first volcanic episode, $V_{1}$ (Ernewein et al., 1988) or Geotimes (Pearce et al., 1981; Alabaster et al., 1982), consists mainly of poorly vesicular brownish pillow basalts, of MOR type, formed during accretion at a spreading center (Lippard et al., 1986; Ernewein et al., 1988; Einaudi et al., 2000; Godard et al., 2003, 2006). The lavas erupted during the second volcanic episode, namely the Lasail lavas (or so-called $V_{2}$ ) consist of discontinuous outcrops of poorly vesicular small, green pillows and thin lava flows (Godard et al., 2006); they belong to off-axial volcanic activity with IAT characteristics. The third volcanic episode, namely the Alley lava (or so-called $V_{3}$ ), has an alkali to transitional nature and belongs 
to a within-plate tectonic setting (Pearce et al., 1981; Alabaster et al., 1982; Ernewein et al., 1988).

The geochemistry and lithological characteristics show similarities between the Lasail $\left(V_{2}\right)$ and Qezil Dash lavas; for example, both have a tholeiitic nature with a low ratio of $\mathrm{Zr} / \mathrm{Hf}$, and are of low-Ti type. The values of $\mathrm{Zr} / \mathrm{Hf}$ ratio for the Lasail and Qezil Dash area were less than 31 (Godard et al., 2006) and 20 respectively.

The geochemical domain of these three volcanic episodes of Oman ophiolite are illustrated in three discriminant diagrams, including $\mathrm{Nb} / \mathrm{Ta}$ versus $\mathrm{Zr} / \mathrm{Hf}$ (Fig. 10A); $\mathrm{Yb}_{\mathrm{N}}$ versus $\mathrm{TiO}_{2}$ (wt.\%) (Fig. 10B), and (La/Yb) $)_{\mathrm{N}}$ versus $\mathrm{TiO}_{2}$ (wt.\%; Fig. 10C). In Figure 10, the Qezil Dash lavas plot in the domain of the Lasail lavas; all of these diagrams clearly demonstrate the geochemical similarity between them.

Most of the Cyprus-type VMS deposits of the Oman ophiolite are restricted to the contact of the $V_{1}$ and $V_{2}$ sequences (Ernewein et al., 1988; Pflumio, 1991). In the Cyprus area, most of the deposits are located between the upper pillow lavas (of olivine basalt composition) and the lower pillow lavas (oversaturated basalts of Oman). The deposits of Lasail and Zoha in the Oman ophiolite are also located between the Geotimes pillow lavas and the Lasail andesite-basaltic lavas. In both regions, there are significant differences in geochemical and lithological composition between the lower and upper lavas of the sulphide deposits. The duration of hydrothermal activity and mineral deposition in this lithostratigraphic setting suggests significant time between the eruptions of these two volcanic episodes. As noted above, the Qezil Dash volcanic rocks recognized as the main host rocks of VMS deposits have similarities to the Lasail unit which is poorly mineralized (Alabaster and Prearce, 1985). The major VMS deposit in the Oman volcanic sequences is restricted to close by the $V_{1}$ and $V_{2}$ boundary. The VMS deposit of Abati located in the SW of Khoy is similar to the VMS deposit of the Skouriotissa area in Cyprus. In both regions, ore deposits are located in the highest part of the meta-basaltic pillow lavas and immediately below the pelagic sedimentary units. The ore body shapes in both cases are stratiform (long lenses). In terms of mineralogy and paragenesis, there are not many differences from mineralisation of known Cyprus-type deposits. In the terms of alteration, similarities between the VMS host rocks of the Khoy and Cyprus areas are significant: the alterations associated with the VMS deposits of Khoy are chloritization adjacent to the mineralisation center and silicification in the stringer zone.

\section{CONCLUSIONS}

The volcanic rocks of Khoy ophiolite include submarine pillow lavas of basaltic composition (Aland volcanic unit) and sub- marine massive sheet lavas of andesitic and andesite-basaltic composition (Qezil Dash volcanic unit). They are recognized as low-Ti and LKT types, and their formation is related to the early stages of island arc generation in a supra-subduction zone tectonic setting. So far, no significant VMS mineralisation has been identified in association with volcanic rocks of the first group, and only some small and dispersed lenses of sulphide mineralisation can be seen in a few regions, such as north of Chaldoran (Iran). In contrast, the second group of volcanic rocks is associated with extensive alteration and sulphide mineralisation, and it contains sulphide occurrences of lense-shaped, stratiform and stockwork types. The chemistry of massive sheet lavas of the Qezil Dash unit indicates enrichment in LILE elements and depletion in HFSE elements, which are recognized as characteristic of SSZ ophiolite lavas (Pearce et al., 1981, 1984; Godard et al., 2006). Tectonically, the Qezil Dash unit is of off-axial volcanic type which includes the formation of arc seamounts in a supra-subduction zone tectonic setting.

Some researchers consider that the formation of syngeneic VMS deposits in the early stages of an island arc with tholeiitic eruptions is possible. In other words, Cyprus-type massive sulphides are also likely to exist at the base of island arc sequences, because in most cases the arc basements will have originated at oceanic ridges (Evans, 2009). Therefore, such sequences should be considered as a promising location for subsequent exploration studies. The geochemical data obtained indicate that the Qezil Dash VMS mineralisation belongs to this stage of island arc formation. In addition, based on geological evidence, it can be concluded that the formation of an island arc has not proceeded from its initial stage. The lack of calc-alkaline lavas and related pyroclastic rocks in the Qezil Dash tholeiites and the cover of lavas with sedimentary rocks (pelagic shale and limestone) attest to this. The geochemical and geological evidence indicates that the Qezil dash VMS-mineralisation host rock in the Khoy ophiolite is comparable with the Lasail unit in the Oman ophiolite. The Lasail units include some weak mineralisation within lavas. Most of the mineralisation in the latter units are located at the contact of Lasail and Geotimes.

According to the models of VMS deposits compared in this paper, such as the Troodos and Oman ophiolites, their sulphide deposits located in the contact of MORB and IAT lavas. Hence, prospecting for these types of mineral deposits in the Khoy ophiolite zone and other ophiolite zones in Iran should be based on geochemical investigations and the determination of the ophiolite lava types and their field relationships.

Acknowledgments. The authors would like to express their sincere thanks to the Kavoshgaran Consulting Engineers (KCE) company, especially Dr. J.A. Sharif, manager of the Qezil Dash project, for all support.

\section{REFERENCES}

Alabaster, T., Pearce, J.A., 1985. The interrelationship between magmatic and ore-forming hydrothermal processes in the Oman ophiolite. Economic Geology, 80: 1-16.
Alabaster, T., Pearce, J.A., Malpas, J., 1982. The volcanic stratigraphy and petrogenesis of the Oman ophiolite complex. Contributions to Mineralogy and Petrology, 81: 168-183. 
Alavi, M., 1994. Tectonic of the Zagros orogenic belt of Iran, new data interpretation. Tectonophysics, 229: 211-238.

Beccaluva, L., 1995. High-Ti and low-Ti ophiolitic belts in Albania: a petrogenetic model for crustal accretion in mid-ocean ridge and supra-subduction oceanic settings. IOS International Ophiolite Symposium Pavia Sept., Abstracts: 9-10.

Beccaluva, L., Di Girolamo, P., Macciotta, G., Morra, V., 1983 Magma affinities and fractionation trends in ophiolites. Ofioliti, 8: 307-324.

Cas, R.A.F., 1992. Submarine volcanism: eruption styles, products, and relevance to understanding the host-rock successions to volcanic-hosted massive sulfide deposits. Economic Geology, 87: 511-541.

Cathelineau, M., 1988. Cation site occupancy in chlorites and illites as a function of temperature. Clay minerals, 23: 471-85.

Cox, D.P., Singer, D.A., 1986. Mineral Deposit Models (Vol. 1693). Bulletin, US Government Printing Office.

Desmons, J., Beccaluva, I., 1983. Mid-Oceanic ridge and Island arc affinities, in ophiolites from Iran. Paleogeographic Implication, Chemical Geology, 39: 39-63.

Dilek, Y., Moores, E.M., 1990. Regional tectonics of the eastern Mediterranean ophiolites. In: Ophiolites, Oceanic Crustal Analogs, Proceeding of the Symposium "Troodos 1987" (eds. J. Malpas, E.M. Moores, A. Panayiotou and C. Xtenophontos) 295-309. Cyprus Geological Survey Department, Nicosia, Cyprus.

Einaudi, F., Pezard, P.A., Cochemé, J.J., Coulon, C., Laverne, C. Godard, M., 2000. Petrography, geochemistry and physical properties of a continuous extrusive section from the Saram Massif, Semail ophiolite. Marine Geophysical Researches, 21 387-408.

Ernewein, M., Pflumio, C., Whitechurch, H., 1988. The death of the accretion zone as evidenced by the magmatic history of the Semail ophiolite (Oman). Tectonophysics, 151: 107-126.

Evans, A.M., 2009. An Introduction to Economic Geology and Its Environmental Impact. John Wiley \& Sons.

Franklin, J.M., Lydon, J.W., Sangster, D.F., 1981. Volcanic-associated massive sulfide deposits. Economic Geology, 75: 485-627.

Franklin, J.M., Gibson, H.L., Jonasson, I.R., Galley., A.G., 2005 Volcanogenic massive sulphide deposits. In: Economic Geology, 100th Anniversary Volume (eds. J.W. Hedenquist, J.F.H Thompson, R.J. Goldfarb and J.P. Richards): 523-560. Society of Economic Geologists

Galley, A.G., Hannington, M.D., Jonasson, I.R., 2007. Volcanogenic massive sulfide deposits. Mineral Deposits of Canada: a Synthesis of Major Deposit-Types, District Metallogeny, the Evolution of Geological Provinces, and Exploration Methods, Geological Association of Canada, Mineral Deposits Division, Special Publication, 5: 141-161.

Geological Survey and Mineral Explorations of Iran (GSI), 1997 Geological map of Khoy in 1:100,000 scales, sheet no. 4967 Geological Survey of Iran.

Godard, M., Dautria, J.M., Perrin, M., 2003. Geochemical variability of the Oman ophiolite lavas: relationship with spatial distribution and paleomagnetic directions. Geochemistry, Geophysics, Geosystems, 4

Godard, M., Bosch, D., Einaudi, F., 2006. A MORB source for low-Ti magmatism in the Semail ophiolite. Chemical Geology, 234: $58-78$

Hassanipak, A.A., Ghazi, A., 2000. Petrology, geochemistry and tectonic setting of the Khoy ophiolite, northwest Iran; Implications for Tethyan tectonics. Journal of Asian Earth Sciences, 18: 109-121.

Herrington, R., Maslennikov, V., Zaykov, V., Seravkin, I., Kosarev, A., Buschmann, B., Armstrong, R., 2005. 6: Classification of VMS deposits: lessons from the South Uralides. Ore Geology Reviews, 27: 203-237.
Imamalipour, A., 2001. Metallogeny of Khoy ophiolite with special regard to sulfide deposits associated with the volcanic rocks of Qezildash area. Ph.D. thesis, University of Shahid Beheshti, Tehran, Iran.

Imamalipour, A., Masoudi, G., 1995. The first report of Cyprus-type massive sulfide mineralization at Qezil Dash area, Khoy, Iran (in Persian). The First Symposium of Geological Society of Iran, Tehran: 35-42.

Imamalipour, A., Rasa, I., 2010. Mineral chemistry of chlorite as a method for geothermometry of hydrothermal alteration from Qezildash sulfide deposit, NW Iran (in Persian with English summary). Iranian Journal of Crystallography and Mineralogy, 18: $223-22$.

Irvine, T.N., Barragar, W.R.A., 1971. A guide to the common volcanic rocks. Canadian Journal, Earth Sciemces, 8: 523-548.

Kurtz, A.C., Derry, L.A., Chadwick, O.A., Alfano, M., 2000. Refractory element mobility in volcanic soils. Geology, 28: 683-686.

Laznicka, P., 1985. Empirical Metallogeny. Depositional Environments Lithologic Associations and Metallic Ores, Vol. 1. Phanerozoic Environments, Associations and Deposits, Developments in Economic Geology, 19.

Lippard, S.J., Shelton, A.W., Gass, I.G., 1986. The Ophiolite of Northern Oman. Geological Society Memoir, vol. 11. Geological Society by Blackwell Scientific Publications, London.

MacLean, W.H., Barrett, T.J., 1993. Lithogeochemical techniques using immobile elements. Geochemical Exploration, 4: 109-133.

Nicolas, A., Boudier, F., Ildefonse, B., Ball, E., 2000. Accretion of Oman ophiolite and the United Emirates ophiolite - discussion of a new structural map. Marine Geophysical Researches, 21: 147-179.

Pearce, J.A., 1996. A user's guide to basalt discrimination diagrams. Trace element geochemistry of volcanic rocks: applications for massive sulfide exploration. Geological Association of Canada, Short Course Notes, 12: 79-113.

Pearce, J.A., Cann, J.R., 1973. Tectonic setting of basic volcanic racks determined using trace element analyses. Earth and Planetary Science Letters, 19: 290-300.

Pearce, J.A., Peate, D.W., 1995. Tectonic implications of the composition of volcanic arc magmas. Annual Review of Earth and Planetary Sciences, 23: 251-285.

Pearce, J.A., Alabaster, T., Shelton, A.W., Searle, M.P., 1981. The Oman ophiolite as a Cretaceous arc-basin complex: evidence and implication. Philosophical Transactions of the Royal Society of London, A300: 299-317.

Pearce, J.A., Lippard, S.J., Roberts, S., 1984. Characteristics and tectonic significance of supra-subduction zone ophiolites. Geological Society, London, Special Publications, 16: 77-94.

Pflumio, C., 1991. Evidence for polyphase oceanic alteration of the extrusive sequence of the Semail ophiolite from the Salahi Block (Oman). In: Ophiolite Genesis and Evolution in the Oceanic Lithosphere (eds. T.J. Peters, A. Nicolas, R.G. Coleman): 313-351. Kluwer Academic Publishers Norwell, MA, USA.

Rollinson, H.R., 1993. Using Geochemical Data Evaluation, Presentation and Interpretation. Longman Scientific and Technical, New York.

Sangster, D.F., 1977. Some grade and tonnage relationships among Canadian volcanogenic massive sulfide deposits. Geological Survey of Canada, Report of Activities, Paper 77-1A: 5-12.

Sawkins, F.J. 1976. Metal deposits related to the intracontinental hotspot and rifting environments. The Journal of Geology, 84: 653-671.

Schandl, E.S., Gorton, M.P., 2002. Application of high field strength elements to discriminate tectonic settings in VMS environments. Economic Geology, 97: 629-642. 
Sengor, A.M.C., Yilmaz, Y., 1981. Tethyan evolution of Turkey: a plate tectonic approach. Tectonophysics, 75: 181-241.

Shanks, W.C., Thurston, R., 2012. Volcanogenic Massive Sulfide Occurrence Model. US Department of the Interior, US Geological Survey.

Sun, S.S., 1982. Chemical composition and origin of the earth's primitive mantle. Geochimica and Cosmochimca Acta, 46: 179-192.

Sun, S.S., McDonough, W.F., 1989. Chemical and isotopic systematics of oceanic basalts: implications for mantle composition and processes. Geological Society, London, Special Publications, 42: 313-345.
Whitney, D.L., Evans, B.W., 2010. Abbreviations for names of rock-forming minerals. American Mineralogist, 95: 185-187.

Wilson, M., 2007. Igneous petrogenesis, a global tectonic approach. Unwin Hyman Ltd., London.

Winchester, J.A., Floyd, P.A., 1977. Geochemical discrimination of different magma series and their differentiation products using immobile elements. Chemical Geology, 20: 325-343.

Wood, D.A., 1980. The application of a ThHfTa diagram to problems of tectonomagmatic classification and to establishing the nature of crustal contamination of basaltic lavas of the British Tertiary Volcanic Province. Earth and Planetary Science Letters,50: 11-30. 